\title{
Anuran interactions with the bromeliad Bromelia balansae in the Brazilian Pantanal
}

\author{
Jiří Moravec ${ }^{1} \&$ Zilca Campos² \\ ${ }^{1}$ Department of Zoology, National Museum (Natural History), Václavské náměstí 68, \\ 11000 Praha 1, Czech Republic \\ ${ }^{2}$ Wildlife Laboratory, Brazilian Agricultural Research Corporation (EMBRAPA) \\ Pantanal, Corumbá, Mato Grosso do Sul, Brazil
}

Moravec J. \& Campos Z., 2020: Anuran interactions with the bromeliad Bromelia balansae in the Brazilian Pantanal. - Journal of the National Museum (Prague), Natural History Series 189: 5-10.

\begin{abstract}
Different frog-bromeliad associations are frequently reported from various habitats of Central and South America. Here, we present the first data on the association of two hylid species (Dendropsophus nanus and Scinax nasicus) with the bromeliad Bromelia balansae in the Brazilian Pantanal. Both treefrog species use rosettes of $B$. balansae as a diurnal shelter and foraging ground.
\end{abstract}

Keywords: Dendropsophus nanus, Scinax nasicus, frog-bromeliad interaction, Pantanal

Received: January 23, 2020 | Accepted: May 20, 2020 | Published on-line: September 3, 2020

Bromelia balansae Mez is a terrestrial bromeliad (Bromeliaceae) with dense rosettes of stiff leaves bearing sharp curved spines. The plant is up to $2 \mathrm{~m}$ high, does not accumulate rainwater (Romero 2006) and forms dense masses by means of stout underground stolons (Spencer 1970). It is distributed in Argentina, Bolivia, Brazil, Colombia and Paraguay (WCSP 2020).

Bromelia balansae (locally known as gravatá) is a common bromeliad of slightly elevated sandy areas of the Brazilian Pantanal (Fernandes et al. 2010, Valério et al. 2016). The high-density cover of B. balansae often surrounds non-inundated "islands" of deciduous or semi-deciduous woody vegetation (cordilheiras) and serves as resting site or shelter of many animals, including diverse mammal species (e.g. Myrmecophaga tridactyla, Pecari tajacu, Procyon cancrivorus, Tayassu pecari, Thrichomys fosteri, and feral populations of Sus scrofa; see Medri et Mourão 2005, Menezes et al. 2018, Antunes et al. 2016). The dense patches of $B$. balansae also provide suitable oviposition places for Caiman yacare (Campos 1993, Campos et Mourão 2015). In addition, fruits, flowers and leaves of B. balansae are an important food resources for many species of animals, such as birds, mammals, reptiles and great diversity of insects (Desbiez et Borges 2010, Paulino-Neto et al. 2016).

During a short-term survey of amphibian and reptile fauna carried out in Nhecôlandia (sub-region of Brazilian Pantanal, Mato Grosso do Sul, Brazil) on 8-12 October 2019 (dry season), individuals of two treefrog species, Dendropsophus nanus (Boulenger, 1889) and Scinax nasicus (Cope, 1862), hidden in rosettes of Bromelia balansae were frequently encountered. Dendropsophus nanus and Scinax nasicus are not bromeligenous species (sensu 


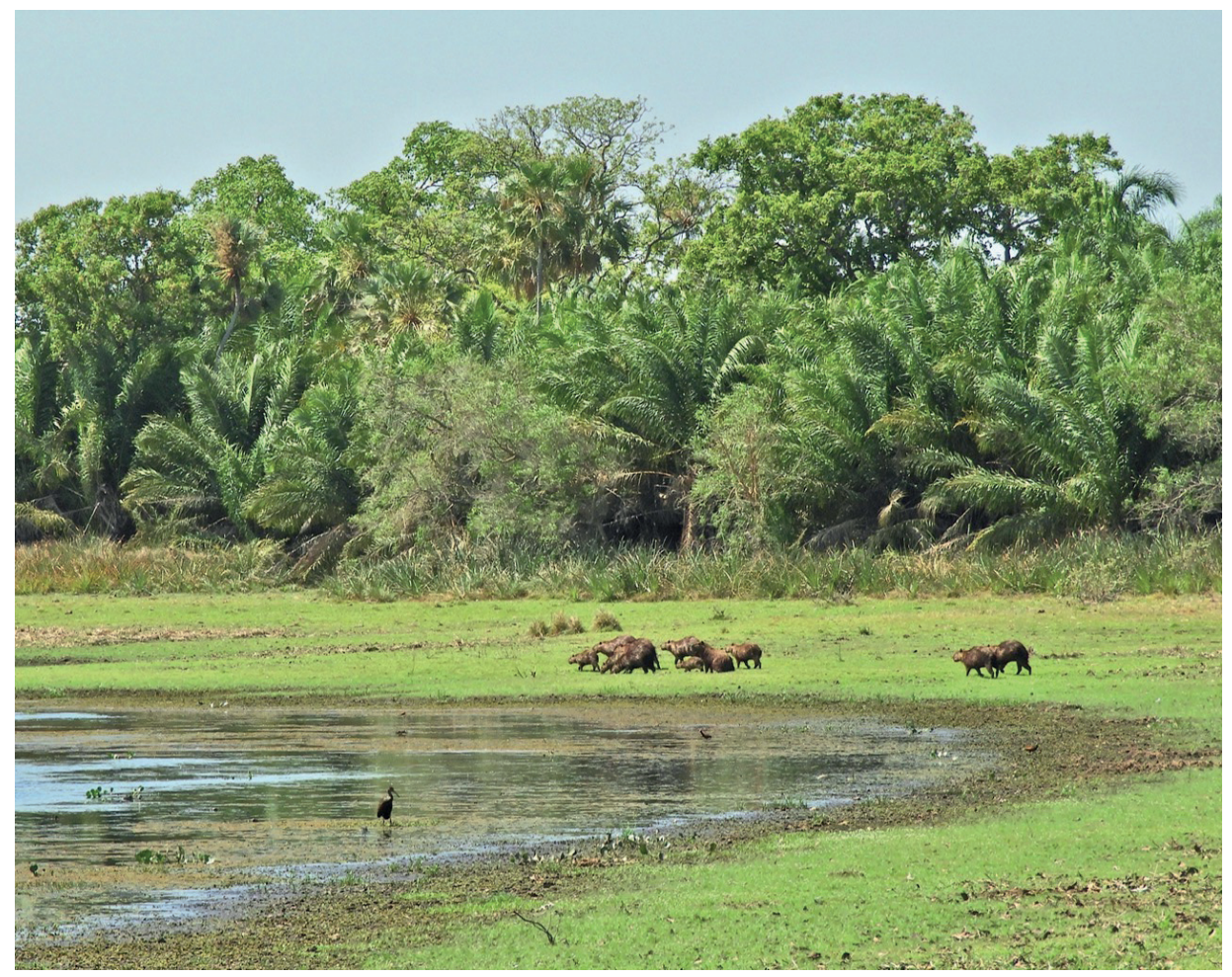

Fig. 1. Marginal belt of Bromelia balansae delimiting grassland from the forested area (Nhumirim, Pantanal). Photo: J. Moravec.

Peixoto 1995), as they breed and develop in free standing water (Gordo et Campos 2003, Uetanabaro et al. 2008). Therefore, the treefrogs apparently used the bromeliads as diurnal shelters and foraging grounds. These findings are reported herein, in order to contribute to knowledge on the biology of the above-mentioned treefrog species, as well as to point out the ecological importance of $B$. balansae in the Pantanal.

The area of Nhecôlandia is a mosaic of three major habitats: pockets of forests, seasonally flooded grasslands (floodplains) and permanent or temporary lagoons. Bromelia balansae usually forms dense marginal understory of the forest "islands", sharply delimiting them from the grassland lying between the forest pockets and lagoons (Fig. 1). In the dry season, the floodplains are grazed by native mammal species (e.g. Hydrochoerus hydrochaeris, Ozotoceros bezoarticus, Mazama sp. and others), and especially by numerous cattle. In consequence, the floodplains are covered by very low vegetation, which cannot provide suitable diurnal shelters for frogs. In contrast to this, the Bromelia patches offer a large selection of shelters both for invertebrate and vertebrate animals, and also form a barrier protecting the forested places from cattle (Campos, Moravec personal obs.).

The growths of Bromelia balansae were inspected on six different localities lying in the vicinity of Nhumirim (18 $59^{\prime} \mathrm{S}, 56^{\circ} 39^{\prime}$ W), a research station run by Empresa Brasileira de Pesquisa Agropecuária (EMBRAPA), Corumbá, on 8-11 October 2019. The linear distances between individual localities were 1-6 km. The distances of bromeliad patches from the water margin of the nearest lagoons ranged between ca. 50-150 m. Every locality was visited once during the day and once after dusk. More than 50 bromeliad rosettes were examined during each visit of each locality. In all, more than 600 rosettes were inspected. 
During the day, treefrog occupancy rate of bromeliad rosettes ranged between ca. 10-25 $\%$. All treefrogs were hidden in the center of the rosette. Individuals of Scinax nasicus were considerably more numerous than individuals of Dendropsophus nanus. In both species, subadults prevailed over adult animals. Usually only one treefrog individual occupied the bromeliad center. However, occasionally two individuals shared the same shelter (Fig. 3) and exceptionally, even 3-5 individuals were hidden together in one place (Fig. 2).

After dusk, the treefrogs foraged on the bromeliad leaves outside the rosette center (Fig. 4). The number of individuals of Scinax nasicus was comparable to the number observed during the day. Both adult and subadult $S$. nasicus were encountered, but the number of Dendropsophus nanus was lower than by day, as adult individuals of this species were nearly

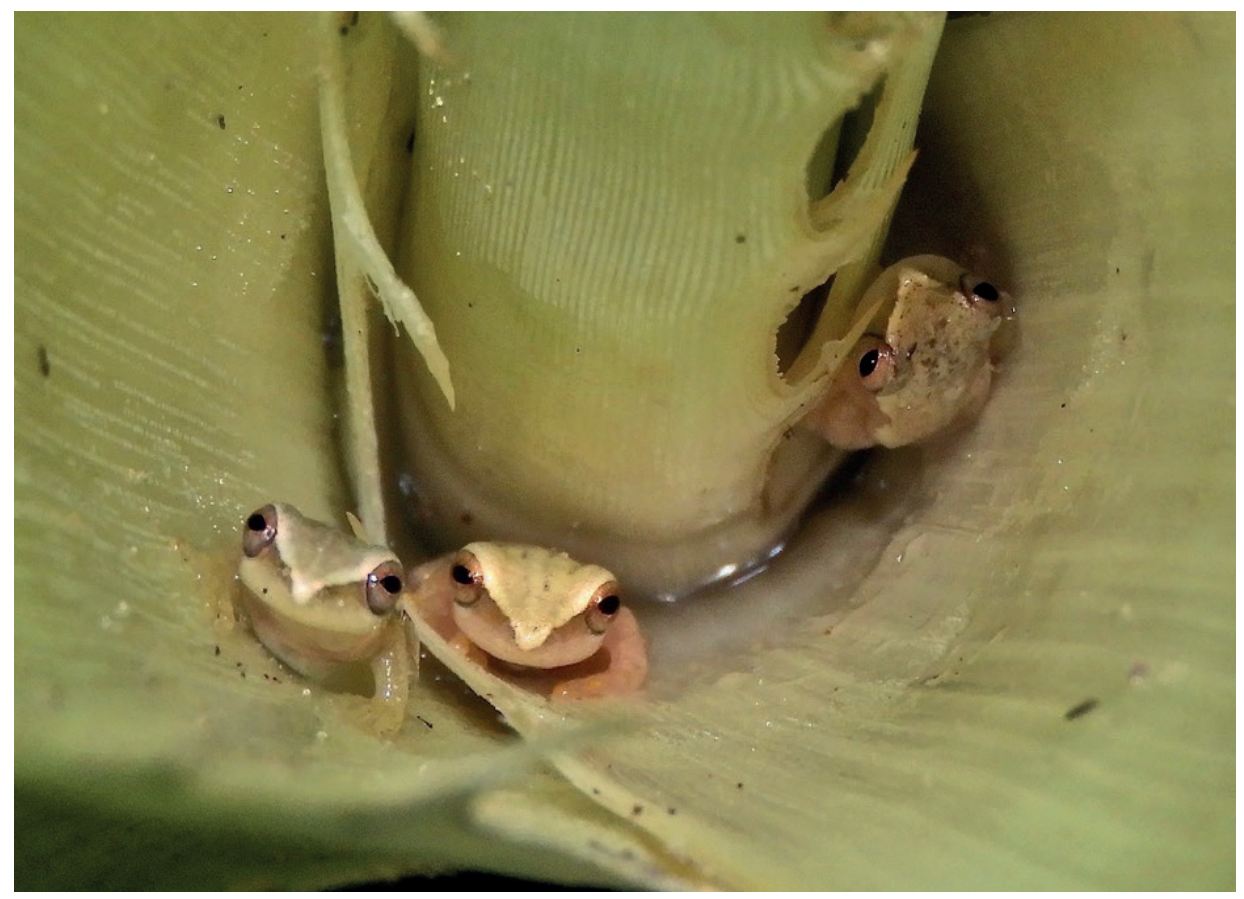

Fig. 2. Three subadult individuals of Dendropsophus nanus in the diurnal shelter in the rosette of Bromelia balansae (Nhumirim, Pantanal). Photo: J. Moravec.

missing in the bromeliads. This finding corresponds to the fact that the adult part of the population of $D$. nanus migrated to breed in the nearby lagoons.

Other hylid species observed at the investigated localities included Boana raniceps, Dendropsophus cf. elianeae, Lysapsus limellum, and Scinax acuminatus. In the case of Dendropsophus cf. elianeae, only one adult specimen was found on the bushes close to bromeliad understory. Males of the remaining species vocalized on the banks of nearby lagoons after sunset.

Dendropsophus nanus and Scinax nasicus probably profit from the association with Bromelia balansae in several ways: (i) the rosette centers surrounded by firm thorny leaves protect the treefrogs from larger predators, (ii) the deep basal parts of rosette centers provide shady and humid shelters (a small amount of water was usually present in the deepest parts of the inspected rosettes), (iii) the presence of diverse groups of arthropods associated 


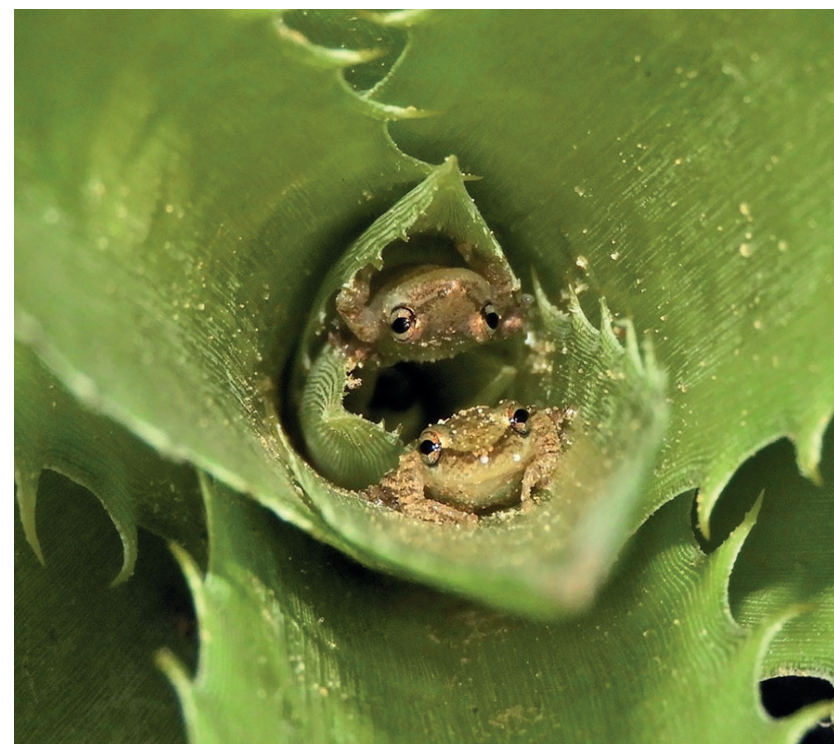

Fig. 3. Two individuals of Scinax nasicus in the diurnal shelter in the rosette of Bromelia balansae (Nhumirim, Pantanal). Photo: J. Moravec.

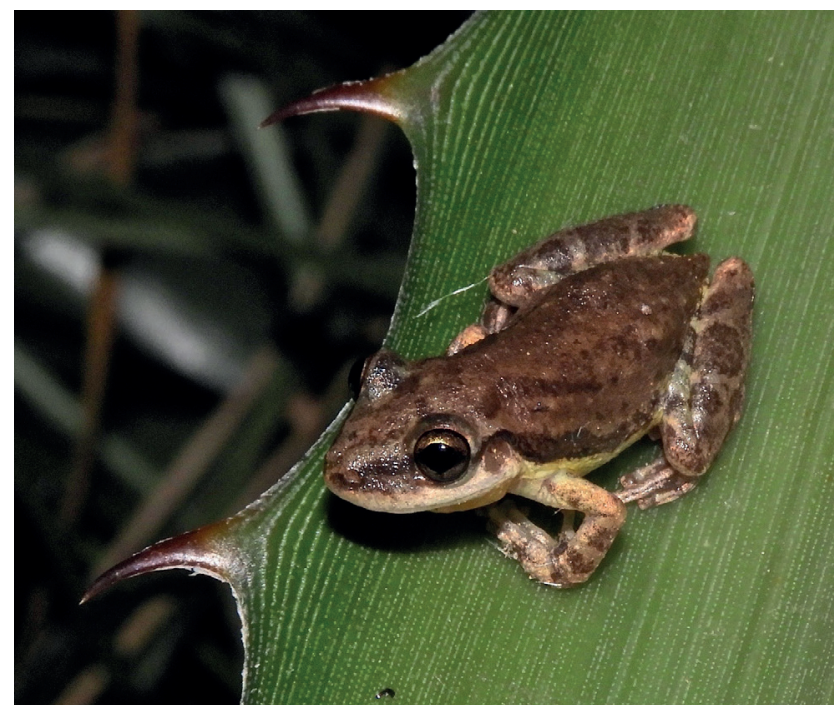

Fig. 4. Adult individual of Scinax nasicus active on the leaves of Bromelia balansae after dusk (Nhumirim, Pantanal). Photo: J. Moravec. with bromeliads ensure sufficient trophic resources; for example, a dense population of saticid spider Psecas chapoda (Fig. 5) inhabited all inspected bromeliad patches (for information concerning association of $P$. chapoda with Bromelia balansae, see e.g. Romero 2006).

Various South and Central American anuran species display many forms of associations with different bromeliad species (Romero et al. 2010, Sabagh 2017). Using bromeliads as diurnal shelter seems to be one of the most common forms of such associations, and has been reported for number of anurans: e.g. Eleutherodactylusjohnstonei (Eleutherodactylidae, see Ovaska 1991), Aparasphenodon brunoi, Boana raniceps, Dendropsophus haraldschultzi, D. nahdereri, Scinax boesemani, $S$. fuscomarginatus, $S$. hayii, $S$. perereca, and Sphaenorhynchus lacteus (Hylidae; see Romero et al. 2010, Sanches et al. 2019). It appears that the benefit from the frog-bromeliad system can be reciprocal. Bromeliads may derive nitrogen from feces of associated animals. Nevertheless, it the case of terrestrial bromeliads which lack extensive phytotelmata (e.g. the genera Ananas and Bromelia), absorption of nitrogen from animal carcasses or feces is much lower than in epiphytic bromeliads having extensive tanks (Romero et al. 2010). The described interaction between treefrogs and Bromelia balansae document another kind of biodiversity support service (sensu Ladino et al. 2019) provided by B. balansae in the Pantanal. 


\section{Acknowledgements}

We thank Denis Tilcara and Luís Alberto Rondon for their help with the fieldwork in the area of the Fazenda Nhumirim. We are grateful to Michal Berec and an anonymous reviewer for their valuable suggestions which helped to improve our manuscript. The research was supported by Empresa Brasileira de Pesquisa Agropecuária (EMBRAPA), Corumbá and the Ministry of Culture of the Czech Republic (DKRVO 2019-2023/6.VI.b, 00023272).

\section{References}

Antunes P.C., Oliveira-Santos L.G.R., Tomas W.M., Forester J.D., Fernandez F.A.S., 2016: Disentangling the effects of habitat, food, and intraspecific competition on resource selection by the spiny rat, Thrichomys fosteri. - Journal of Mammalogy 97: 1738-1744. https://doi. org/10.1093/jmammal/gyw140

Campos Z., 1993: Effect of habitat on survival of eggs and sex radio of hatchlings of Caiman crocodilus yacare in the Pantanal, Brazil. - Journal of Herpetology 27: 127-132.

Campos Z., Mourão G., 2015: Camera traps capture images of predators of Caiman crocodilus yacare eggs (Reptilia: Crocodylia) in Brazil's Pantanal wetlands. - Journal of Natural History 49: 977-982. https://doi.org/10.2307/1564927

Desbiez J.L.A., Borges P.A.L., 2010: Density, habitat selection and observations of South American coati Nasua nasua in the Central region of the Brazilian Pantanal wetland. Small Carnivore Conservation 42: 14-18.

Fernandes I.M., Signor C.A., Penha J. (eds.), 2010: Biodiversidade no Pantanal de Poconé [Biodiversity of the Pantanal de Poconé]. - Centro de Pesquisa do Pantanal, Cuiabá, 196 pp. [In Portuguese]

Gordo M., Campos Z., 2003: Listagem dos Anuros da Estação Ecológica Nhumirim e Arredores, Pantanal Sul [List of anurans of the ecological field station Nhumirim and its surroundings, Pantanal Sul]. - Documentos 58, EMBRAPA, Corumbá, 21 pp. [In Portuguese]

Ladino G., Ospina-Bautista F., Varón J.E., Jerabkova L., Kratina P., 2019: Ecosystem services provided by bromeliad plants: A systematic review. - Ecology and Evolution 9: 73607372. https://doi.org/10.1002/ece3.5296

Medri Í.M., Mourão G., 2005: A brief note on the sleeping habits of the Giant Anteater Myrmecophaga tridactyla Linnaeus (Xenarthra, Myrmecophagidae). - Zoologia 22: 1213-1215. https://doi.org/10.1590/s0101-81752005000400061

Menezes J.F S., Mourão G.M., Kotler B.P., 2018: Understory cover increases patch use in rodent Thrichomys fosteri. - Ethology, Ecology \& Evolution 30: 267-276. https://doi.org/ 10.1080/03949370.2017.1354921

Ovaska K. 1991: Reproductive phenology, population structure, and habitat use of the frog Eleutherodactylus johnstonei in Barbados, West Indies. - Journal of Herpetology 25: 424-430. https://doi.org/10.2307/1564764

Paulino-Neto H.F., Nakano-Oliveira E. de Assis Jardim M.M., Vasconcellos-Neto J., 2016: Frugivory in Bromelia balansae (Bromeliaceae): The effect of seed passage through the 
digestive system of potential seed dispersers on germination in an Atlantic rainforest, Brazil. - Journal of Ecosystem \& Ecography 6, 4: 1-8.

Peixoto O.L., 1995: Associação de anuros e bromeliáceas na Mata Atlântica [Anuran-bromeliad associations in the Atlantic forest]. - Revista Universidade Rural, Série Ciências da Vida 17: 75-83. [In Portuguese]

Romero G.Q., 2006: Geographic range, habitats, and host plants of bromeliadliving jumping spiders (Salticidae). - Biotropica 38: 522-530. https://doi. org/10.1111/j.1744-7429.2006.00173.x

Romero G.Q., Nomura F., Gonçalves A.Z., Dias N.Y.N., Mercier H., Conforto E.de C., Rossa-Feres D.de C., 2010: Nitrogen fluxes from treefrogs to tank epiphytic bromeliads: an isotopic and physiological approach. - Oecologia 162: 941-949. https://doi.org/10.1007/ s00442-009-1533-4

Sabagh L.T., Ferreira R.B., Rocha C.F.D., 2017: Host bromeliads and their associated frog species: further considerations on the importance of species interactions for conservation. - Symbiosis 73: 201-211. https://doi.org/10.1007/s13199-017-0500-9

Sanches P.R., Santos F.P., Correa J.G., França P.F., Sousa J.C., Cantuária P.C., Costa-Campos C.E., 2019: Anurans associated with the bromeliad Bromelia goeldiana L. B. Sm" on a floodplain in northern Brazil, eastern Amazon. - Herpetology Notes 12: 431-433.

Spencer R.W., 1970: Bromelia balansae and its close relatives. - Bromeliad Society Bulletin 20, 4: 89.

Uetanabaro M., Prado C.P.A., Rodrigues D.J., Gordo M., Campos Z., 2008: Guia de campos do Pantanal e olanaltos de etorno. Fieldguide to the anurans of the Pantanal and surrounding Cerrados. - UFMS, Campo Grande, UFMT, Cuiabá, 192 pp.

Valério L.M., Dorado-Rodrigues T.F., Chupel T.F., Penha J., Strüssmann C., 2016: Vegetation structure and hydroperiod affect anuran composition in a large Neotropical Wetland. Herpetologica, 72: 181-188. https://doi.org/10.1655/herpetologica-d-14-00069.1

WCSP, 2020: World Checklist of Selected Plant Families. Facilitated by the Royal Botanic Gardens, Kew. - Published on the Internet; http://wcsp.science.kew.org/ [Accessed on 11 January 2020] 